\title{
PANDANGAN MUFASIR INDONESIA TERHADAP ISU-ISU HAK ASASI MANUSIA
}

\author{
Ahmad Mujahid \\ Universitas Islam Negeri Antasari Banjarmasin \\ ahmadmujahid@uin-antasari.ac.id
}

\begin{abstract}
This article argues that the attitude of Indonesian mufassir is not always parallel in respond to the concept of Human Rights. This is shown from our discussion of three contextual issues in human rights: freedom of religion, freedom to find a mate, and death sentence, which are exemplified by comparing to the three Indonesian mufassir. Hamka's Tafsir al-Azhar, Hasbi ash-Shiddieqy's Tafsir al-Nur and Tafsir al-Bayan, and Quraish Shihab's Tafsir Al-Mishbah. The article concludes: First, in respond to the human rights issues, Indonesian commentators tend to be responsive. All three exegetes denied those who claimed that Islam was spread with violence and those who opposed the death penalty. Second, on the relationship between human rights and Islam, the commentators have similarities and differences with human rights. Among these similarities, for example, is the issue of religious freedom. As for the issue of freedom to choose a mate and a death sentence, they are taking a different position from human rights. On the issue of death penalty, the commentators emphasize to not only looking from the side of the killer, but also from the right of the murder.
\end{abstract}

Keywords: Indonesian Mufassir, Human Rights, Freedom of Religion, Interfaith Marriages, Death Sentence.

Abstrak: Artikel ini berargumen bahwa sikap para mufasir Indonesia tidak selalu sama dalam merespon Hak Asasi Manusia (HAM). Hal itu ditunjukan dari pembahasan terhadap tiga isu kontekstual dalam HAM, yaitu: kebebasan beragama, kebebasan mencari jodoh, dan vonis hukuman mati. Ketiga isu tersebut dieksemplifikasi dengan membandingkan tiga tokoh mufasir Indonesia: Hamka dengan Tafsir al-Azhar, Hasbi ash-Shiddieqy dengan Tafsir al-Nur dan Tafsir al-Bayan, serta Quraish Shihab dengan Tafsir Al-Mishbah. Artikel ini menyimpulkan bahwa: Pertama, dalam merespon isu-isu HAM, para mufasir Indonesia cenderung responsif. Ketiganya membantah pihakpihak yang mengklaim bahwa Islam disebarkan dengan kekerasan dan pihak-pihak yang menentang hukuman mati. Kedua, terkait relasi HAM dengan Islam, para mufasir memiliki persamaan dan perbedaan 
dengan HAM. Di antara persamaan itu, misalnya, isu tentang kebebasan beragama. Adapun dalam isu kebebasan memilih jodoh dan vonis hukuman mati, mereka berbeda dengan HAM. Sedang dalam isu hukuman mati, para mufasir memandang untuk tidak hanya melihat dari sisi pembunuh, tapi juga dari sisi terbunuh yang telah kehilangan hak.

Kata Kunci: Mufasir Indonesia, Hak Asasi Manusia, Kebebasan Beragama, Perkawinan Beda Agama, Hukuman Mati.

\section{Pendahuluan}

Di era modern ini, Hak Asasi Manusia (HAM) merupakan satu isu yang menyedot perhatian dan menjadi agenda yang penting di banyak negara, tak ketinggalan negara-negara Islam. Isu HAM bahkan menjadi faktor pertimbangan kebijakan luar negeri setiap negara. Lebih dari itu, keharusan adanya penghormatan terhadap HAM ini menjadi keharusan dalam hubungan internasional. ${ }^{1}$ Suatu negara yang dinilai dan diketahui mengabaikan HAM, besar kemungkinan akan menjadi sasaran kritik dan diisolir dari pergaulan antar bangsa. HAM di sini dimaksudkan sebagai hak-hak tertentu, yang melekat secara eksistensial dalam identitas kemanusiaan tanpa melihat kebangsaan, agama, jenis kelamin, status sosial, pekerjaan, kekayaan atau karakteristik etnik, budaya dan perbedaan sosial lainnya. ${ }^{2}$

Konsep HAM selama ini dianggap produk dari Barat, walaupun ini masih diperdebatkan, karenanya hampir di semua masyarakat nonBarat, wacana HAM itu menjadi bahan debat yang aktual. Mereka memunculkan pertanyaan-pertanyaan, misalnya: Apakah Barat boleh memaksakan paradigma mereka terhadap masyarakat non-Barat? ${ }^{3}$ Sementara sudah menjadi suatu kebenaran publik bahwa masing-

\footnotetext{
${ }^{1}$ Simela Victor Muhamad, "Pemajuan dan Perlindungan Hak Asasi Manusia Dalam konteks Hubungan Internasional dan Indonesia," dalam Kajian Vol. 13 No. 4 (2008): 619-649. Lihat juga Louise I. Shelley, "Human Rights as an International Issue," dalam Annals of the American Academy of Political and Social Science, Vol. 506, (1989), 42-56.

${ }^{2}$ Marie-Bénédicte Dembour, "What Are Human Rights? Four Schools of Thought," dalam Human Rights Quarterly Vol. 32, No. 1 (2010): 1-20

${ }^{3}$ Zehra F. Kabasakal Arat, "Forging a Global Culture of Human Rights: Origins and Prospects of the International Bill of Rights," dalam Human Rights Quarterly, Vol. 28, No. 2 (2006), 416-437. Menurut Zehra, klaim bahwa HAM murni berasal dari Barat perlu diteliti ulang. Karena negara-negara anggota PBB non-Barat juga terlibat dalam pembahasan draft HAM. Bandingkan juga dengan Ann Elizabeth Mayer, Islam Human Rights: Tradition and Politics (Colorado: Westview Press, 1999), 10.
} 
masing masyarakat dan lingkungan kebudayaan mempunyai acuan normatif dengan standar yang berbeda-beda pula. Haruskah suatu acuan normatif yang lahir dari konteks kebudayaan tertentu diberlakukan secara universal? ${ }^{4}$ Apakah ini bukan merupakan bagian dari invasi kultural dunia Barat terhadap belahan dunia lain? Jika dikaitkan dengan Islam, pertanyaannya adalah apakah konsep HAM sejalan dengan prinsip Islam? ${ }^{5}$

Terkait relasi antara Islam dan HAM ini, Majelis Ulama Indonesia (MUI) dalam Fatwanya Nomor: 6/Munas VI/MUI/2000 Tentang Hak-Hak Asasi Manusia (HAM), menyebutkan beberapa pertimbangan atau persyaratan penerimaan HAM Universal, di antaranya adalah: pertama, bahwa HAM tidak berlaku di ruang hampa dan sampai sekarang belum ada konsensus kesamaan pemahaman penafsiran dan penerapan HAM, sehingga masing-masing negara dimungkinkan untuk memberikan penafsiran dan pemahaman yang sesuai dengan nilai-nilai budaya dan susila mereka. Kedua, bahwa pasalpasal dari Universal Declaration of Human Rights (UDHR) terkesan sangat mengedepankan hak-hak dan kebebasan individu dan mengabaikan keseimbangan antara hak dan kewajiban, keseimbangan antara kepentingan individu dan kepentingan umum, serta keseimbangan antara kebebasan dan tanggung jawab. Ketiga, bahwa adanya beberapa pasal dalam UDHR yang tidak selaras atau bertentangan dengan agama Islam, yakni: a. pasal 16 ayat 1 dan 2 tentang kebebasan dalam mencari jodoh, perkawinan dan perceraian; b. pasal 18 tentang kebebasan berganti agama; c. pasal 23 tentang pekerjaan. Keempat, bahwa negara Indonesia telah ikut menandatangani Deklarasi Kairo tahun 1996 tentang HAM. ${ }^{6}$

Dalam pertimbangan fatwanya di atas, MUI secara lantang menyuarakan adanya pasal-pasal dalam UDHR yang tidak selaras atau bertentangan dengan agama Islam, khususnya: a. pasal 16 ayat 1 dan 2 tentang kebebasan dalam mencari jodoh, perkawinan dan perceraian;

\footnotetext{
${ }^{4}$ Susan Waltz, "Reclaiming and Rebuilding the History of the Universal Declaration of Human Rights," dalam Third World Quarterly, Vol. 23, No. 3 (2002): 437-448.

5Daniel Price, "Islam and Human Rights: A Case of Deceptive First Appearances," dalam Journal for the Scientific Study of Religion, Vol. 41, No. 2 (2002): 213-225. Lihat juga Katerina Dalacoura, Islam, Liberalism and Human Rights: Implications for International Relations (London: I.B. Tauris \& Co Ltd, 1998), 1

${ }^{6} \mathrm{Http}: / /$ mui.or.id/mui/produk-mui/fatwa-mui/fatwa-komisi-fatwa-mui/hak-asasimanusia.html/diakses 2 Agustus 2018.
} 
b. pasal 18 tentang kebebasan berganti agama; c. pasal 23 tentang pekerjaan. $^{7}$

Artikel ini akan mengupas beberapa isu dalam Hak Asasi Manusia yang sering menjadi trending topic pada beberapa kesempatan, yaitu hak kebebasan beragama, hak kebebasan mencari jodoh, dan kontroversi hukuman mati. Tiga isu ini akan penulis sorot dari disiplin keilmuan tafsir dengan mengetengahkan tiga mufasir kenamaan Indonesia: Hamka dengan karyanya Tafsir al-Azhar, Hasbi Al-Shiddieq dengan karyanya Tafsir al-Bayan dan Tafsir al-Nur, serta Quraish Shihab dengan karyanya Tafsir Al-Mishbah. Pemilihan tiga mufasir didasarkan pada beberapa pertimbangan; pertama, ketiganya merupakan produk tafsir lengkap 30 juz, sehingga uraian intratekstual akan lebih menyeluruh. Kedua, mereka menggunakan metode tafsir tabliti (eksplanatif), sehingga penafsiran yang dipaparkan lebih rinci dan detail. Ketiga, mereka hidup di era modern, saat di mana wacana HAM berkembang.

\section{Historisitas HAM}

Wacana HAM sebenarnya sudah muncul semenjak abad ke-17 dan ke-18 M. Bahkan jika dilacak lebih jauh, menurut Patnaik, wacana tersebut sudah muncul pada masa Plato (427-406 SM). ${ }^{8}$ Wacana yang muncul pada abad ke-17 dan ke-18 bermula dari reaksi terhadap absolutisme para raja dan kelompok feodalis yang ditujukan terhadap rakyat yang diperintah atau manusia yang dipekerjakan. Pada masa itu, dikotomi masyarakat secara hirarkhis diklasifikasi menjadi dua lapisan: lapisan atas di satu sisi, yang memiliki hak-hak, dan lapisan bawah di lain pihak, yang hanya memiliki kewajiban-kewajiban. Dalam berinteraksi, kelompok atas yang minoritas (ningrat) lebih menunjukkkan sifat kesewenang-wenangan, hingga puncaknya memerkosa kodrat kemanusiaan bagi kelas bawah, yang kemudian pada fase berikutnya melahirkan sistem perbudakan.

Secara historis, ide tentang HAM berasal dari gagasan tentang hak-hak alami, ${ }^{9}$ oleh karenanya HAM dianggap sebagai bagian dari

${ }^{7}$ Ibid.

8J. K. Patnaik, "Human Rights: The Conœept and Perspectives: A Third World View," dalam The Indian Journal of Political Science Vol. LXV, No. 4, (2004): 499-514. Plato dianggap meletakkan dasar perlindungan terhadap hak warga negara dan bukan warga negara.

'Paul R. Epstein, "Human Rights and Natural Laws," dalam Health and Human Rights, Vol. 2, No. 2 (1997): 1-4. Lihat juga A. Masyhur Effendi, Dimensi/Dinamika 
hakikat kemanusiaan yang paling fundamental. Di dunia Barat, ide tentang HAM merupakan hasil perjuangan kelas sosial yang menuntut tegaknya nilai-nilai dasar kebebasan dan persamaan. Secara kronologis tercermin dengan lahirnya 'Magna Charta' (Piagam Besar) pada 15 Juni 1215 di Inggris, sebagai bagian pengakuan (pemaksaan) Raja Jhon Lockland atas hak-hak rakyatnya. ${ }^{10}$ Sayangnya, Piagam di atas masih sering dilanggar, sehingga dibuat lagi Bill of Rights oleh Raja William II pada 1689 yang juga dari Inggris yang berisi pengakuan bahwa hakhak rakyat dan anggota parlemen tidak boleh diganggu gugat. Kemudian disusul dengan The Declaration of Independence pada $1788 .{ }^{11}$

Proses perkembangan HAM mencapai puncaknya ketika perang dunia II usai, PBB pada tanggal 10 Desember 1948 yang didukung oleh sebagian besar anggota PBB mendeklarasikan The Universal of Human Rights yang berisi 30 pasal. ${ }^{12}$ Pasal 1 dan 2 berisi pernyataan umum bahwa manusia mempunyai hak yang didapatkan sejak lahir, tanpa diskriminasi dan tanpa dasar apapun. Pasal 3 hingga pasal 27 berkaitan dengan ekonomi sosial, sedangkan tiga pasal terakhir (28 hingga 30) menegaskan kebutuhan akan sebuah kerangka kerja di mana hak-hak di atas dapat direalisasikan. Keputusan di atas dimantapkan lagi dengan dua dokumen lainnya yang merupakan hasil kesepakatan internasional sebagai acuan bagi pengertian HAM. Keduanya adalah International Convent on Economic and Cultural Right (31 Januari 1976) dan International Convent on Civil and Political Rights (23 Maret 1976). ${ }^{13}$

\section{Islam dan HAM: Sebuah Pendekatan Dialogis}

Dalam menyikapi hubungan antara Islam dan HAM, para sarjana Muslim mempunyai dua perbedaan yang mendasar. Pertama, menerima konsep HAM yang dideklarasikan oleh PBB pada tahun

Hak Asasi Manusia Dalam Hukum Nasional dan Internasional Jakarta: Ghalia Indonesia, 1994), 9-17. Disebutkan dalam aliran Stoa seperti yang dikemukakan oleh Zeno (336-264 SM) bahwa ala mini diatur oleh logika dan manusia memilikinya, karenanya manusia akan menaati hukum tersebut. Manusia diberi kebebasan memilih tapi tidak boleh melanggar hukum. Bandingkan dengan Dalacoura, Islam, Liberalism and Human Rights, 6-7.

${ }^{10}$ Effendi, Dimensi/Dinamika Hak, 30.

${ }^{11}$ Ibid., 30-1.

${ }^{12}$ Musdah Mulia, Islam dan Hak. Asasi Manusia: Konsep dan Implementasi (Yogyakarta: Naufan Pustaka, 2010), 3.

${ }^{13}$ Mayer, Islam Human Rights, 18. 
1948 dan menganggapnya sebagai bagian yang integral dalam ajaran Islam. Karenanya, pasal-pasal yang terdapat dalam Deklarasi Universal Hak Asasi Manusia juga harus dipraktekkan di negara-negara Muslim. Kedua, menganggap bahwa DUHAM tahun 1948 adalah berasal dari inisiasi negara-negara Eropa yang pasalnya banyak bertentangan dengan teologi Islam. Karenanya, tidak bisa semua pasal yang ada dalam DUHAM diterapkan dalam negara-negara Muslim.

Musdah Mulia, misalnya, menekankan bahwa konsep HAM sejalan dengan ajaran Islam. Menurutnya, Islam mengenal konsep tauhid yang memiliki efek pembebasan diri dan sosial. Di antara implikasi pembebasan sosial adalah paham egalitarianisme yang berpaham bahwa semua manusia sama di hadapan Tuhan, dan yang membedakan hanya ketakwaannya. ${ }^{14}$

Ebrahim Moosa melihat dari sisi perbedaannya. Menurutnya, dalam The Universal Islamic Declaration of Human Rights (UIDHR) pada Konferensi Islam Internasional di Paris, 19 September 1980 secara eksplisit menjelaskan bahwa kewajiban lebih didahulukan daripada hak dan hanya dengan melaksanakan kewajiban tersebut yang akan menghasilkan sejumlah hak yang akan diperoleh. ${ }^{15}$ Di sini kelihatan perbedaan signifikan dalam memaknai HAM. Jika HAM versi Barat lebih terkesan penonjolan hak di atas kewajiban, sedangkan HAM versi Islam sebaliknya, kewajiban didahulukan daripada hak. Glenn L. Roberts melihatnya lebih mendasar lagi. HAM versi Islam bersumber dari Alquran dan Sunah, sedangkan versi Barat berasal dari hukum alam yang didasarkan pada logika manusia dan filsafat kemanusiaan. ${ }^{16}$

Kedua pihak di atas, pada dasarnya, mempunyai kesamaan persepsi bahwa Islam memiliki ajaran-ajaran tentang Hak Asasi Manusia. Bahkan, dari sisi historis, menurut pihak kedua, Islam lebih awal menginisiasi persoalan HAM yakni pada 14 abad yang lalu walaupun istilah HAM itu sendiri belum dikenal. ${ }^{17}$ Dalam sejarah Islam dikenal adanya Piagam Madinah (abad VI M) yang pasal-

\footnotetext{
${ }^{14}$ Mulia, Islam dan Hak Asasi, 2

${ }^{15}$ Ebrahim Moosa, Islam Progresif: Refleksi Dilematis tentang HAM, Modernitas dan HakHak Perempuan di dalam Hukum Islam, terj. Yasrul Huda (Jakarta: ICIP, 2004), 28-29.

${ }^{16}$ Glenn L. Roberts, Islamic Human Rights and International Law (Florida: University of Houston Law Center, 2003), 50.

${ }^{17}$ Sulieman Abdul Rahman al-Hageel, Human Rights in Islam and Refutation of The Misconceiced Allegations Associated with These Rights (Arab Saudi: King Fahad National Library Index, 1999), 46. Lihat juga Mulia, Islam dan Hak, 9.
} 
pasalnya banyak mengatur tentang hak-hak asasi manusia, ${ }^{18}$ berbeda dengan negara-negara Eropa yang baru mengangkat persoalan HAM ini pada abad ke-17 dan ke-18, sebagai reaksi terhadap keabsolutan Raja dan Kaum Feodal. ${ }^{19}$

\section{Sikap Mufasir Terhadap Isu-isu HAM \\ 1. Kebebasan Beragama}

Ada beberapa ayat yang seringkali dikutip ketika membahas kebebasan seseorang untuk memeluk agama, di antaranya adalah QS. al-Baqarah [2]: $256^{20}$ dan QS. al-Kahf [18]: 29. ${ }^{21}$

Ketika menafsirkan QS. al-Baqarah [2]: 256, Hamka terlebih dahulu menyebutkan bahwa konteks ayat ini adalah tentang permintaan seorang ayah dari kaum ansar kepada Rasulullah yang ingin anaknya masuk Islam. Anak tersebut memeluk Yahudi karena dipelihara orang Yahudi Bani Nađ̣ir. Saat terjadinya peristiwa pengusiran Yahudi Bani Naḍir dari Madinah akibat mengkhianati perjanjian dengan kaum Muslim, sang ayah memohon kepada Rasulullah untuk menarik anaknya tersebut untuk menjadi Muslim kalau perlu dengan paksa. ${ }^{22}$ Menurut riwayat Ibn 'Abbās, Rasulullah

\footnotetext{
${ }^{18}$ Lima pokok dari Piagam Madinah: 1. Prinsip persaudaraan bahwa semua berasal dari satu asal, karenanya semua bersaudara. 2. Prinsip saling menolong dan melindungi Penduduk Madinah. 3. Prinsip melindungi yang lemah dan teraniaya. 4. Prinsip saling menasehati. 5. Prinsip kebebasan beragama. Mulia, Islam dan Hak, 10. ${ }^{19}$ Sadia Rehan, "Origin and Development of Human Rights in Islam and the West: A Comparative Study," dalam International Journal of Social Science and Humanity, Vol. 3, No. 1, (2013): 36-38. Lihat juga Najid Jauhar, "Islam, Demokrasi, dan HAM Sebuah Benturan Filosofis dan Teologis," dalam Jurnal Ilmu sosial dan Ilmu Politik, Volume 11, Nomor 1, Juli (2007): 31-62.

${ }^{20}$ Terjemahnya: "Tidak ada paksaan untuk (memasuki) agama (Islam); sesungguhnya telah jelas jalan yang benar daripada jalan yang sesat. Karena itu barangsiapa yang ingkar kepada Taghut dan beriman kepada Allah, maka sesungguhnya ia telah berpegang pada buhul tali yang amat kuat yang tidak akan putus. Dan Allah Maha Mendengar lagi Maha Mengetahui."

${ }^{21}$ Terjemahnya: "dan katakanlah: kebenaran itu datangnya dari Tuhanmu; maka barangsiapa yang ingin (beriman) hendaklah ia beriman, dan barangsiapa ingin (kafir) biarlah ia kafir. Sesungguhnya Kami telah sediakan bagi orang-orang zalim itu neraka, yang gejolaknya mengepung mereka. Dan jika mereka meminta minum, niscaya mereka akan diberi minum dengan air seperti besi yang mendidih yang menghanguskan muka. Itulah minuman yang paling buruk dan tempat istirahat yang paling jelek."

${ }^{22}$ Hamka, Tafsir al-Ažbar, Vol. III (Jakarta: Pustaka Panjimas, 2003), 29
} 
hanya memanggil anak tersebut dan disuruh memilih, apakah sudi masuk Islam atau tetap dalam Yahudi. ${ }^{23}$

Fakta di atas, menurut Hamka, menjelaskan bahwa ada perbedaan soal politik dan soal keyakinan agama. Yahudi Bani Nađ̣ir diusir dari Madinah karena pengkhianatan mereka terhadap perjanjian konstitusi yang telah disepakati bersama bahkan mereka berusaha membunuh Nabi yang berposisi sebagai Kepala Negara Madinah. Soal keyakinan, mereka tidak dipaksa untuk pindah dari agama Yahudi. ${ }^{24}$

Ayat di atas, menurut Hamka, adalah dasar teguh Islam. Ia mengkritik kalangan yang menuduh Islam dimajukan dan disebarkan dengan pedang. Menurutnya, kalangan tersebut harus melihat sumber utama Islam: Alquran dan Hadis. Keduanya tidak pernah mengajarkan paksaan dalam beragama, khususnya ayat ini. Hamka juga menguatkan dengan fakta sejarah, baik dari masa klasik hingga berikutnya, Islam tidak pernah memaksakan agama. ${ }^{25}$

Untuk QS. al-Kahf [18]: 29, Hamka menjelaskan bahwa karena manusia itu sudah diberi akal dan jelasnya kebenaran, maka terserah bagi dia untuk beriman atau tidak. Jika beriman dia akan selamat dan sebaliknya jika kafir ia akan menanggung akibat dari kekafirannya tersebut. $^{26}$

Hasbi ash-Shiddieqy menjelaskan maksud dari QS. al-Baqarah [2]: 256 adalah jangan memaksa orang untuk menjadi Islam. Islam adalah agama yang jelas dan terang. Beriman kepada agama itu adalah urusan hati, tak ada seorangpun yang dapat memaksanya. ${ }^{27}$ Karenanya, menurut dia, jihad dalam Islam adalah untuk membela dakwah islamiyah. Tuhan tidak membina urusan iman secara paksa tapi atas dasar sukarela. ${ }^{28}$ Sebagaimana Hamka, ia juga mengkritik kalangan yang menuduh Islam disebarkan dengan pedang. Menurutnya, sejarah sudah cukup membuktikan itu. Bahkan Nabi sendiri seringkali disakiti bahkan beribadah secara diam-diam pada masa awal Islam, dan di pihak lain kaum Quraisy terus menyiksa kaum muslimin hingga mereka terpaksa berhijrah. ${ }^{29}$

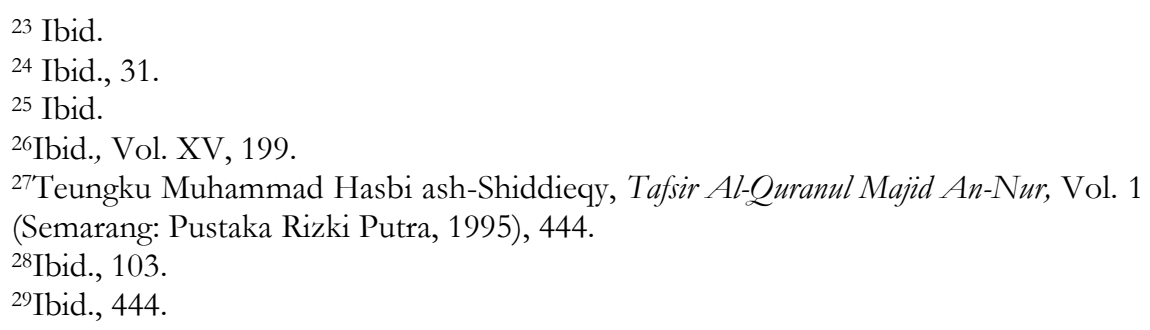


Ketika menafsirkan QS. al-Baqarah [2]: 256, Quraish Shihab menyebutkan bahwa Allah tidak memerlukan paksaan dalam pemelukan agama, sekiranya Dia berkehendak tentu dengan mudah menjadikan semua penghuni dunia beriman. ${ }^{30}$ Menurutnya, tidak ada paksaan menganut agama disini maksudnya adalah menganut akidahnya. Jika seseorang menjatuhkan pilihannya pada suatu agama, Islam contohnya, maka ia terikat untuk melaksanakan perintahperintahnya. Dia akan terancam sanksi jika tidak melaksanakan perintah-perintah tersebut. Ia tidak boleh berkata, "Allah telah memberi saya kebebasan untuk shalat atau tidak, berzina atau tidak." ${ }^{\prime 31}$

Senada dengan penafsiran QS. al-Baqarah [2]: 256, ketika menafsirkan QS. al-Kahf [18]: 29, Quraish Shihab, sembari mengingatkan konteks ayat ini tentang permintaan tokoh-tokoh Quraisy untuk mengusir orang-orang miskin dan lemah dari majlis Nabi Muhammad, menyebutkan bahwa tidak ada paksaan bagi para orang-orang Quraisy untuk beriman atau tetap dalam agama nenek moyangnya. ${ }^{32}$

Jika ayat-ayat dan tafsiran di atas berbicara tentang kebebasan masuk agama tertentu seperti Islam, maka bagaimanakah keadaan orang Islam yang keluar dari Islam alias murtad. Apakah ini diperbolehkan? Karena bagian dari kebebasan beragama adalah bebas memeluk dan keluar dari suatu agama.

Ketiganya, Hamka, ash-Shiddieqy dan Quraish Shihab, tidak ketinggalan menanggapi perkara murtad ini. Mengacu kepada QS. alMáidah [5]: 54,33 Hamka menanggapi ringan terhadap orang yang murtad ini. Menurutnya, soal murtad ini pasti akan terjadi dalam beragama. Orang murtad ini tidak perlu diratapi, karena iman mereka

\footnotetext{
${ }^{30}$ QS. Yunus [10]: 99, yang terjemahnya: "Dan jikalau Tuhanmu menghendaki, tentulah beriman semua orang yang di muka bumi seluruhnya. Maka apakah kamu (hendak) memaksa manusia supaya mereka menjadi orang-orang yang beriman semuanya?" Lihat juga M. Quraish Shihab, Tafsir Al-Mishbab: Pesan, Kesan, dan Keserasian al-Qur'an, Vol. 5 (Jakarta: Lentera Hati, 2009), 513.

${ }^{31}$ Ibid., Vol. 1, 668

${ }^{32}$ Ibid., Vol. 7, 285

${ }^{33}$ Terjemahnya: "Hai orang-orang yang beriman, barangsiapa di antara kamu yang murtad dari agamanya, maka kelak Allah akan mendatangkan suatu kaum yang Allah mencintai mereka dan merekapun mencintai-Nya, yang bersikap lemah lembut terhadap orang yang mukmin, yang bersikap keras terhadap orang-orang kafir, yang berjihad dijalan Allah, dan yang tidak takut kepada celaan orang yang suka mencela. Itulah karunia Allah, diberikan-Nya kepada siapa yang dikehendaki-Nya, dan Allah Maha Luas (pemberian-Nya), lagi Maha Mengetahui."
} 
sebenarnya kosong. Hanya karena rayuan duniawi ia sudah berubah. ${ }^{34}$ Orang-orang yang murtad itu akan diganti Allah dengan yang lain. Menurutnya, sejarah telah mencatat bahwa ketika Bani Asad, kabilah Fazzarah, Ghațān, dan Bani Salim telah murtad dari Islam, mereka kemudian diganti kabilah Ash'ari, Kindah, Sukūn, dan kabilah Ṭayip dari Yaman. ${ }^{35}$

Hasbi ash-Shiddieqy, jika dilihat dalam Tafsir al-Bayan tidak banyak memberi komentar, dia hanya menerjemahkan ayat ini secara harfíyah. ${ }^{36}$ Sikapnya dilatari oleh metode yang dipakainya dalam penafsiran kitab tersebut yaitu ijmăti. ${ }^{37}$ Berbeda dengan tafsirnya yang lain yaitu Tafsir al-Nur, ia menjelaskan bahwa perkara murtad ini adalah biasa dan tidak memelaratkan Islam. Allah, menurutnya, tidak menegakkan agamanya dengan orang munafik dan berpenyakit jiwa tapi dengan orang yang benar imannya dan mencintai-Nya sepenuh hati. ${ }^{38}$ Lebih rinci dari Hamka, dia mencatat ada 11 kabilah yang murtad di masa awal Islam; 3 di masa Nabi, 7 di masa Abū Bakr, dan 1 di masa 'Umar b. al-Khațāab. ${ }^{39}$

Quraish Shihab juga senada dalam menafsirkan ayat ini. Menurutnya, janganlah bersedih jika ada orang murtad dan bergegas dalam kekufuran, karena Allah sudah berjanji kepada Rasulullah bahwa agama Islam akan dipeluk dan dibela oleh banyak orang. ${ }^{40}$

Dari pernyataan-pernyataan di atas, dapat diketahui pendapat tiga mufasir tersebut. Mereka bertiga sama-sama menolak adanya unsur paksaan dalam memeluk suatu agama. Agama adalah urusan hati, tidak bisa dipaksa. Hamka dan ash-Shiddieqy menolak pendapat yang mencap bahwa Islam disebarkan dengan pedang. Menurut mereka, Islam tidak mengajarkan kekerasan dan sejarah telah berbicara tentang fakta tersebut.

Sedangkan untuk kasus murtad atau keluar dari agama, khususnya dari agama Islam, mereka bertiga menilai tidak ada yang perlu

\footnotetext{
${ }^{34}$ Hamka, Tafsir al-Azhar, Vol. VI, 285-9.

35Ibid., 289-290.

${ }^{36}$ Ash-Shiddieqy, Al-Bayan: Tafsir Penjelas Al-Quranul Karim (Semarang: Pustaka Rizki Putra, 2002), 265.

${ }^{37}$ Nashruddin Baidan menyebutkan ada empat metode penafsiran: ijmali (ringkas dan global), tablili (analitis), muqarin (komparatif) dan mawdu'i (tematik). Lihat Nashrudddin Baidan, Metodologi Penafsiran Al-Qur'an (Yogyakarta: Pustaka Pelajar, 2000), x-xiii.

${ }^{38}$ Ash-Shiddieqy, Tafsir Al-Quranul Majid An-Nur, Vol. 2, 1064.

${ }^{39}$ Ibid., 1062

${ }^{40}$ Shihab, Tafsir Al-Mishbah, Vol. 3, 157.
} 
dirisaukan. Islam tidak memerlukan orang-orang murtad yang imannya lemah. Islam hanya tegak oleh orang-orang yang benar imannya dan benar-benar mencintai Islam. Dalam sejarah Islam klasik, orang-orang murtad akan digantikan oleh pemeluk-pemeluk Islam baru yang lainnya.

Dari paparan pendapat para mufasir Indonesia di atas, sangat tampak bahwa, dalam hal kebebasan beragama baik masuk ataupun keluar dari Islam, mereka sangat toleran. Bagi mereka, perkara agama adalah masalah keyakinan. Tidak boleh ada paksaan dalam bentuk apapun. Ini juga sejalan dengan DUHAM pasal 18 yang berbunyi: "Setiap orang berhak atas kebebasan pikiran, keinsafan batin dan agama. Dalam hak ini termasuk kebebasan berganti agama atau kepercayaan dan kebebasan untuk menyatakan agama atau kepercayaannya dengan cara menganjurkannya, mengamalkannya, beribadat dan menaatinya, baik secara sendiri-sendiri maupun bersama-sama dengan orang lain, baik di tempat umum maupun di tempat tersendiri." ${ }^{\prime 4}$

\section{Kebebasan Mencari Jodoh}

Isu yang juga hangat dilontarkan dalam Hak Asasi Manusia adalah kebebasan untuk menentukan jodoh. Dalam isu ini, yang sering menjadi perdebatan sengit dan kontroversi adalah perkawinan beda agama dan perkawinan sejenis. ${ }^{42}$ Perkawinan sejenis ini tidak terlalu menarik untuk dibahas disebabkan: pertama, tidak ada nash dalam Alquran yang samar akan ketidakbolehannya. Kedua, secara alami, perkawinan model ini menyalahi kodrat. Ketiga, perkawinan ini hanya terjadi di masyarakat Modern yang mayoritas bukan Muslim. Islam dengan terang benderang melarang perkawinan model ini.

\footnotetext{
${ }^{41}$ Ikhwan, Hak. Asasi Manusia dalam Islam (Jakarta: Logos Wacana Ilmu, 2004), 61-62. ${ }^{42}$ Akronim populernya adalah LGBT (Lesbian, gay, biseksual, transgender). Kampanye ini marak disebarkan lewat berbagai media termasuk media internet lewat, misalnya, situs www.hrc.org, dan www.lgbtcenters.org, Di Indonesia sendiri, tokoh yang getol mengkampanyekan kesetaraan hak terhadap komunitas LGBT ini adalah Prof. Dr. Siti Musdah Mulia, M.A. Ia mempertanyakan kenapa masyarakat menerima perkawinan model hetero dan menolak model homo, bisek dan orientasi seksual lainnya. Padahal, menurutnya, yang demikian itu hanya konstruk sosial. Lihat Musdah Mulia, Islam dan Hak. Asasi Manusia, 287.
} 
Berbeda dengan perkawinan beda agama yang, diantaranya, dijelaskan dalam QS al-Baqarah [2]: 22143 dan QS al-Mä'idah [5]: 5. ${ }^{44}$ Terhadap soal ini, beberapa ulama masih berbeda pendapat. Hamka, misalnya, mengawali penafsiran QS. al-Baqarah [2]: 221, dengan mengutip latar turunnya ayat yaitu cerita tentang sahabat Marthad alGhaznawi dengan 'Ināq, seorang perempuan musyrik Mekkah. Hamka dalam ayat ini secara tegas, melarang adanya perkawinan antara seorang muslim dengan musyrik. Menurutnya, di antara macam kafäab yang pokok dalam perkawinan adalah kesamaan agama. Seorang muslim tidak sekufu dengan orang musyrik. ${ }^{45}$ Cuma, menurutnya, ada keringanan atau kebolehan perkawinan seorang muslim laki-laki dengan wanita abl al-kitab, Yahudi dan Nasrani. Hanya saja, ia seakan mensyaratkan laki-laki yang boleh kawin tersebut adalah yang kuat agamanya. ${ }^{46}$ Kebolehan ini tidak berlaku untuk sebaliknya, seorang muslimah dilarang kawin dengan laki-laki abl al-kitāb. ${ }^{47}$

Walaupun perkawinan seorang muslim laki-laki dengan wanita abl al-kitāb dibolehkan, menurutnya, pada kenyataannya banyak memberikan kemudaratan. Di antara efek negatif yang muncul adalah tingginya angka perceraian, dan anak-anak mereka tidak lagi menentu

\footnotetext{
${ }^{43}$ Terjemahnya, "QS. al-Baqarah [2]: 221, "Dan janganlah kamu menikahi wanitawanita musyrik, sebelum mereka beriman. Sesungguhnya wanita budak yang mukmin lebih baik dari wanita musyrik, walaupun dia menarik hatimu. Dan janganlah kamu menikahkan orang-orang musyrik (dengan wanita-wanita mukmin) sebelum mereka beriman. Sesungguhnya budak yang mukmin lebih baik dari orang musyrik, walaupun dia menarik hatimu. Mereka mengajak ke neraka, sedang Allah mengajak ke surga dan ampunan dengan izin-Nya. Dan Allah menerangkan ayatayat-Nya (perintah-perintah-Nya) kepada manusia supaya mereka mengambil pelajaran."

${ }^{44}$ Terjemahnya, "Pada hari ini dihalalkan bagimu yang baik-baik. Makanan (sembelihan) orang-orang yang diberi Al Kitab itu halal bagimu, dan makanan kamu halal (pula) bagi mereka. (Dan dihalalkan mangawini) wanita yang menjaga kehormatan diantara wanita-wanita yang beriman dan wanita-wanita yang menjaga kehormatan di antara orang-orang yang diberi Al Kitab sebelum kamu, bila kamu telah membayar mas kawin mereka dengan maksud menikahinya, tidak dengan maksud berzina dan tidak (pula) menjadikannya gundik-gundik. Barangsiapa yang kafir sesudah beriman (tidak menerima hukum-hukum Islam) maka hapuslah amalannya dan ia di hari kiamat termasuk orang-orang merugi."

${ }^{45}$ Hamka, Tafsir al-Azhar, Vol. II, 256.

${ }^{46}$ Ibid., 257 \& Vol. VI, 143-4.

${ }^{47}$ Ibid., Vol. II, 257.
} 
agamanya. ${ }^{48}$ Bahkan secara empiris, ia menyebutkan banyak pemudi muslimah yang keluar dari Islam akibat perkawinan model ini. ${ }^{49}$

Serupa juga pendapatnya Hasbi ash-Shiddieqy. Ia mengikuti makna nash QS. al-Baqarah [2]: 221 yang secara tegas mengadakan perkawinan dengan orang-orang musyrik, baik laki-laki ataupun perempuan. Sedangkan dengan abl al-kitâb, merujuk pada QS. alMă'idah [5]: 5, ia membedakannya. Laki-laki muslim diperbolehkan mengawini wanita abl al-kitāb. Namun untuk perempuan muslimah dilarang untuk kawin dengan laki-laki abl al-kitāb. Alasannya, menurutnya, perempuan tidak mempunyai hak seperti laki-laki. Selain itu, para lelaki yang mengendalikannya dapat membawanya ke jalan yang sesat dan merusak akidahnya. ${ }^{50}$

Quraish Shihab membedakan antara perkawinan dengan musyrik dan dengan abl al-kitäb. Perkawinan antara seorang muslim dengan wanita musyrik atau sebaliknya adalah dilarang. Sedangkan perkawinan antara seorang muslim dengan wanita-wanita abl al-kitāb masih dibolehkan, karena adanya nash (QS al-Mäidah [5]: 5) dan tidak untuk sebaliknya. ${ }^{51}$ Syarat wanita abl al-kitāb yang boleh dikawini adalah al-mubsanat. ${ }^{52}$ Namun di akhir penafsiran QS. al-Baqarah [2]: 221, Quraish Shihab menekankan kecenderungan melarang perkawinan seorang muslim dengan wanita abl al-kitāb atas dasar kemaslahatan, bukan atas dasar teks Alquran. Sehingga perkawinan model ini dalam sudut hukum Islam adalah makruh. Karena, dalam perkawinan diperlukan hubungan yang harmonis dan faktor keimanan anak di masa mendatang juga perlu diperhatikan. ${ }^{53}$

Pendapat-pendapat yang diutarakan oleh para mufasir Indonesia di atas sedikit banyak sejalan dengan beberapa mufasir yang lain. AlJașsāạ $(370 \mathrm{H})$, misalnya, menegaskan bahwa, sesuai dengan QS. alBaqarah [2]: 221, perkawinan dengan penganut syirik adalah diharamkan, kecuali dengan wanita-wanita abl al-kitāb. Ia memperkuat dengan berbagai jalur riwayat yang mayoritas memperbolehkan

\footnotetext{
${ }^{48}$ Ibid., 258

49 Ibid., 260.

${ }^{50}$ Ash-Shiddieqy, Tafsir Al-Quranul Majid An-Nur, Vol. 1, 372.

${ }^{51}$ Shihab, Tafsir Al-Mishbah, Vol. 1, 578.

${ }^{52}$ Al-Muhssanàt berarti wanita terhormat yang selalu menjaga kesuciannya dan sangat menghormati dan mengagungkan kitab suci. Lihat M. Quraish Shihab, Wawasan AlQur'an: Tafsir Maudhu'i atas Pelbagai Persoalan Umat (Jakarta: Mizan, 2005), 198.

${ }^{53}$ Shihab, Tafsir Al-Mishbah, Vol. 1, 580-1.
} 
perkawinan dengan wanita abl al-kitāb yang terpelihara dan merdeka, kecuali Ibn 'Umar. ${ }^{54}$ Menurut Al-Jașșāṣ, perkawinan dengan wanita abl al-kitāb sudah lumrah terjadi di kalangan muslim klasik seperti yang dipraktekkan oleh sahabat 'Uthmān b. 'Affān yang mengawini seorang wanita Nashrani yang bernama Nà'ilah b. al-Faräfishah al-Kalbiyah, Ṭalhạ bin 'Ubaydillāh yang mengawini seorang wanita penduduk Syam yang beragama Yahudi, dan Hudhayfah yang mengawini seorang wanita Yahudi. ${ }^{55}$ Mengutip dari 'Ațā', menurut al-Jaṣsạạ, praktek yang dilakukan para sahabat ini hanya sebuah kelonggaran yang bersifat situasional. Saat itu, kuantitas muslimah sangat sedikit berbeda dengan era setelahnya. ${ }^{56}$

Beragam pendapat dari para mufasir di atas, khususnya mufasir Indonesia, menegaskan bahwa mereka hanya memperbolehkan perkawinan beda agama dari seorang laki-laki muslim dengan wanita abl al-kitāb dan tidak untuk sebaliknya. Sedangkan agama yang lain mereka tidak merekomendasikannya. Jika dikonfrontir dengan DUHAM maka akan berbeda. Dalam DUHAM pasal 16 ayat 1 disebutkan:

Orang dewasa baik laki-laki maupun perempuan, dengan tidak dibatasi oleh kebangsaan, kewarganegaraan, atau agama, berhak untuk mencari jodoh dan membentuk keluarga. Mereka mempunyai hak yang sama dalam masalah perkawinan, di dalam hubungan perkawinan, dan di dalam perceraian..$^{57}$

\section{Kontroversi Hukuman Mati}

Di antara ayat Alquran yang menyinggung tentang hukuman mati adalah QS. al-Baqarah [2]: 178-179 dan QS. al-Má-idah [5]: $45 .{ }^{58}$

\footnotetext{
${ }^{54}$ Abụ Bakr Aḥmad al-Rāzi Al-Jașsạạ, Aḥkāam al-Qur'an, vol. 1 (Beirut: Dār al-Fikr, 1993), 454-458; vol. 2, 459-465. Al-Rāzi cenderung sependapat dengan Ibn 'Umar. Menurutnya, tidak ada lagi penganut Yahudi dan Nashrani yang monotheisme. Keduanya sudah politeisme. Lihat Muhammad Fakhruddin b. Diyā' al-Din 'Umar al-Rāzi, Tafsir al-Fakhr al-Rǟi al-Mushtahar bi al-Tafsir al-Kabir wa Mafätih al-Ghayb, vol. 6 (Beirut: Dār al-Fikr, 2005), 52.

${ }^{55}$ Al-Jașṣaș, Aḅkām al-Qur'an, vol. 1, 455. Lihat juga Waḥbah al-Zuhayli, Al-Tafsìr alMunir $\bar{f} \bar{i}$ al-'Aqidah wa al-Shari 'ah wa al-Manhaj, vol. 3 (Damaskus: Där al-Fikr, 1998), 95.

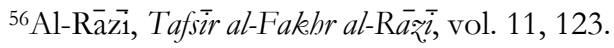

${ }^{57}$ Ikhwan, Hak Asasi, 66.

${ }^{58}$ Terjemahnya QS. al-Baqarah [2]: 178, "Hai orang-orang yang beriman, diwajibkan atas kamu qishaash berkenaan dengan orang-orang yang dibunuh; orang merdeka
} 
Menurut Hamka, model qisas.s yang dikenal dalam Islam ini sebenarnya adalah semacam revisi terhadap qisas model jahiliyyah yang lebih beraroma balas dendam. Pada masa jahiliyyah, ketika seorang budak dibunuh oleh budak maka budak si pembunuh dengan tuannya harus dibunuh, ketika perempuan dibunuh oleh seorang perempuan maka yang membayar adalah laki-laki dari perempuan si pembunuh tersebut. Model qișas ini dirubah oleh Islam, dengan aturan yang dihukum mati adalah yang membunuh itu saja bukan yang lain. ${ }^{59}$

Di samping itu, menurut Hamka ayat ini juga masih memberi solusi alternatif, yaitu pemberian maaf oleh keluarga korban. Walaupun diberi maaf, si pembunuh juga diberikan kewajiban untuk membayar diyat jika keluarganya menuntut. ${ }^{60}$ Kecuali jika keluarga korban menyedekahkan diyat atau tidak meminta diyat (QS al-Nisā' [4]: 92).

Hukum qisas ini, menurut Hamka, haruslah diputus dengan cara ișlāh (berdamai) di antara 2 keluarga. Kalau keluarga terbunuh tidak mau menerima diyat, maka hakim tidak bisa memaksa. Hukuman mati pun harus dijatuhkan. Terkait dengan hukuman mati yang disebutkan Alquran ini, menurut Hamka, harus diyakini sebagai cara yang baik. Hanya saja dalam hukuman mati ini ada beberapa proses: qișas dasar pertama, maaf yang kedua, dan diyat di bawah bimbingan hakim yang ketiga. $^{61}$

Serupa dengan Hamka, ash-Shiddieqy menjelaskan hukum qișas. yang dikandung dalam ayat ini adalah revisi dari hukum jahiliyyah yang lebih beraroma balas dendam. Alquran mengajarkan hukuman hanya dijatuhkan kepada yang melakukan, bukan yang lain. ${ }^{62}$ Alquran juga memberikan solusi menghindari hukuman qișas ini dengan membayar diyat kepada keluarga terbunuh jika mereka memberikan

dengan orang merdeka, hamba dengan hamba, dan wanita dengan wanita. Maka barangsiapa yang mendapat suatu pemaafan dari saudaranya, hendaklah (yang memaafkan) mengikuti dengan cara yang baik, dan hendaklah (yang diberi maaf) membayar (diat) kepada yang memberi maaf dengan cara yang baik (pula). Yang demikian itu adalah suatu keringanan dari Tuhan kamu dan suatu rahmat. Barangsiapa yang melampaui batas sesudah itu, maka baginya siksa yang sangat pedih."

${ }^{59}$ Hamka, Tafsir al-Az̧har, Vol. II, 105

${ }^{60} \mathrm{Ibid} ., 107$

${ }^{61}$ Ibid., 108

${ }^{62}$ Ash-Shiddieqy, Tafsir Al-Quranul Majid An-Nur, Vol. 1, 283-4. 
maaf. ${ }^{63}$ Tentang diyat ini, ash-Shiddieqy menyebutkan bahwa ada perbedaan harta yang harus dibayar, terkecuali dari keluarga terbunuh membebaskannya secara suka rela. ${ }^{64}$

Menanggapi pihak yang tidak setuju dengan adanya hukuman mati, ash-Shiddieqy mengatakan kalaupun ada negara-negara maju yang tidak melaksanakan hukuman mati, hal tersebut tidak dapat dijadikan peraturan umum. Karena menurutnya, qișas secara adil dan persamaan itulah yang dapat mendidik bangsa. Jika tidak diterapkan, akan menjadikan penjahat berani melakukan pembunuhan. ${ }^{65}$ Hikmah hukuman mati ini hanya akan dipahami secara komprehensif oleh kalangan ulu al-albāb. ${ }^{66}$

Quraish Shihab tidak jauh berbeda dengan dua mufasir pendahulunya di atas. Menurutnya, dasar hukuman qisas ada adah persamaan, tidak boleh lebih. Jika dimaafkan harus membayar diyat atau tebusan yang tidak melampui batas. Pemberian maaf adalah perbuatan terpuji dan tidak boleh dipaksakan. ${ }^{67}$

Ketika menafsirkan QS. al-Baqarah [2]: 179, Quraish Shihab menekankan bahwa hikmah hukuman mati ini hanya dipahami oleh ulu al-albāb yaitu orang yang memiliki akal murni yang tidak diselubungi oleh "kulit" yakni kabut ide yang dapat melahirkan kerancuan dalam berpikir. Lubb itu adalah isi atau saripati. Kacang, misalnya, memiliki kulit yang menutupi isinya $(l u b b){ }^{68}$

Quraish Shihab juga menanggapi kalangan yang menentang hukuman mati. Menurutnya, semua peraturan yang dibikin, baik dari Tuhan ataupun manusia, tujuannya adalah untuk kemaslahatan manusia itu sendiri. Manusia disini tidak dimaksudkan sebagai individu tapi "masyarakat manusia" secara kolektif. ${ }^{69}$ Maka, ketika seseorang membunuh satu manusia, eksesnya tidak hanya kepada si korban, tapi juga kepada "masyarakat manusia" secara umum. ${ }^{70}$

\footnotetext{
${ }^{63}$ Ibid., 285.

${ }^{64}$ Ibid., 893. Lihat tafsir QS. al-Nisā' (4): 92.

${ }^{65}$ Ibid., 287.

${ }^{66}$ Ibid., 286.

${ }^{67}$ Shihab, Tafsir Al-Mishbah, Vol. 1, 473-4.

${ }^{68}$ Ibid.

${ }^{69}$ Ibid., 476.
}

${ }^{70}$ QS. Al-Má'idah [5]: 32, “Oleh karena itu Kami tetapkan (suatu hukum) bagi Bani Israil, bahwa: barangsiapa yang membunuh seorang manusia, bukan karena orang itu (membunuh) orang lain, atau bukan karena membuat kerusakan dimuka bumi, maka seakan-akan dia telah membunuh manusia seluruhnya. Dan barangsiapa yang 
Terhadap tudingan bahwa hukuman mati adalah sesuatu yang kejam, Quraish Shihab, mengutip pendapat pakar hukum Islam, menuturkan bahwa hukuman mati akan dilihat kejam jika hanya dilihat dari sisi hak pelaku pembunuhan. Seharusnya harus dilihat dari sisi yang lain yaitu si korban yang dirampas hak hidupnya dan keluarga korban yang harus menanggung derita akibat perbuatan pelaku pembunuhan. ${ }^{71}$ Di samping itu, menurutnya, dalam Alquran, bentuk kebaikan itu tidak hanya ditunjukkan dengan rahmat dan kasih sayang tapi bisa juga berupa sanksi terhadap kesalahan. Kasih sayang ada tempatnya dan ketegasan ada pada tempatnya. ${ }^{72}$

Menanggapi tuduhan bahwa hukuman mati atau qisass itu sendiri juga menghilangkan nyawa yang lain, Quraish Shihab menjelaskan bahwa yang nampak memang demikian, tapi yang tidak nampak adalah hati keluarga korban yang bergejolak. Terkadang bisa berupa balas dendam yang melebihi batas keadilan. Karenanya daripada mengakibatkan jatuhnya banyak korban yang tidak bersalah, lebih baik menghukum mati si pelaku. ${ }^{73}$ Jika dikatakan hukuman mati malah dapat menyuburkan balas dendam, Quraish Shihab balik bertanya, "berhasilkah kemanusian (tidak menghukum mati) mengikis habis dendam yang membara dalam jiwa manusia?" 74 Alquran sendiri memberi alternatif. Jika keluarga korban memberi maaf, maka si pelaku bisa bebas dari hukuman mati.

Sedangkan dalih bahwa pelaku pembunuhan adalah pengidap penyakit jiwa sehingga dengan sendirinya harus dibebaskan dari hukuman mati, menurut Quraish Shihab, dalih ini akan berbahaya. Semua pelaku kejahatan akan beralasan sakit jiwa. Namun jika berdasarkan pemeriksaan dari lembaga yang bertanggungjawab tentu hukumunnnya akan berbeda. ${ }^{75}$

Ketiga mufasir di atas sepakat bahwa hukuman mati atau qisas layak untuk dijatuhkan kepada pelaku atas dasar kejahatan yang

memelihara kehidupan seorang manusia, maka seolah-olah dia telah memelihara kehidupan manusia semuanya. Dan sesungguhnya telah datang kepada mereka rasul-rasul Kami dengan (membawa) keterangan-keterangan yang jelas, kemudian banyak diantara mereka sesudah itu sungguh-sungguh melampaui batas dalam berbuat kerusakan dimuka bumi."

${ }^{71}$ Shihab, Tafsir Al-Mishbah, Vol. 1, 477.

${ }^{72}$ Ibid.

${ }^{73} \mathrm{Ibid}$.

${ }^{74}$ Ibid.

${ }^{75}$ Ibid., 478. 
dilakukannya. Qișas yang disebutkan dalam Alquran adalah sebagai bentuk revisi terhadap qisas sas yang diterapkan pada masa turunnya Alquran. Masyarakat Quraisy pada saat itu menerapkan qișas tidak proporsional dan berlebihan. Alquran menetapkannya atas dasar persamaan.

Pemahaman para mufasir Indonesia di atas persis dengan penafsiran mufasir lainnya. Al-Jașșāṣ mengatakan bahwa dengan QS. al-Baqarah [2[: 178-179 di atas, hukuman mati memang layak dijatuhkan kepada pelaku pembunuhan. Ini sesuai dengan perbuatan mereka. Menurutnya, qișas itu sendiri secara linguistik bermakna menimpakan suatu perbuatan terhadap seseorang sebagaimana ia melakukannya terhadap orang lain. ${ }^{76}$

Al-Rāzi menegaskan bahwa pelaksanaan qisass bukan berarti menghilangkan kehidupan tapi sebaliknya. Qisass ini malah akan menimbulkan kehidupan yang lebih luas. Logikanya adalah jika seseorang yang akan membunuh dan ia mengetahui bahwa ia akan dihukum mati lalu ia tidak jadi membunuh, berarti ini telah menyelamatkan dua orang. Pertama, calon korban yang tidak jadi dibunuh. Kedua, calon pembunuh yang jika ia jadi membunuh, ia akan dihukum mati. ${ }^{77}$

Pemahaman yang diutarakan oleh para mufasir di atas, tidak sejalan dengan kalangan yang menolak vonis hukuman mati atas dasar Hak Asasi Manusia. Argumen-argumen mereka, bahwa hukuman mati adalah berasal dari upacara pengorbanan suci agama, berakar pada upaya balas dendam, jenis hukuman purba, biadab, dan tidak relevan lagi pada masyarakat beradab. ${ }^{78}$

\section{Kesimpulan}

Isu-isu Hak Asasi Manusia (HAM) yang marak diperbincangkan secara luas, juga tidak luput dari perhatian mufasir Indonesia seperti Hamka, Hasbi ash-Shiddieqy dan Quraish Shihab. Dari tiga isu HAM

\footnotetext{
${ }^{76}$ Al-Jașṣạ̄, Aḅkāam al-Qur'an, vol. 1, 187.

${ }^{77}$ Al-Räzi, Tafsì al-Fakhr al-Räzi. Vol. 5, 54. Lihat juga, Al-Zuhayli, Al-Tafsìr alMunir, vol. 1, 107.

${ }^{78}$ Mulia, Islam dan Hak Asasi, 264. Musdah Mulia menyebutkan ada 8 alasan mengapa perlu penghapusan hukuman mati, diantaranya, bertentangan dengan esensi semua ajaran agama, bertentangan dengan nilai-nilai demokrasi, bertentangan dengan prinsip-prinsip hak asasi manusia, alat penindasan, sering dijatuhkan pada salah orang, dan lain-lain.
} 
yang menarik, kebebasan beragama, kebebasan memilih jodoh dan vonis hukuman mati, ada dua aspek yang bisa disimpulkan: Pertama, dalam merespon isu-isu HAM, para mufasir Indonesia cenderung responsif. Ketiganya membantah pihak-pihak yang mengklaim bahwa Islam disebarkan dengan kekerasan dan pihak yang menentang hukuman mati.

Kedua, terkait relasi HAM dengan Islam, peneliti melihat para mufasir memiliki persamaan dan perbedaan dengan HAM. Dalam hal kebebasan beragama, mereka mempunyai kesamaan pendapat dengan HAM. Tetapi dalam hal kebebasan memilih jodoh dan vonis hukuman mati, mereka berbeda. Bagi para mufasir Indonesia, kebebasan dalam perkawinan dibatasi, khususnya dalam masalah agama. Berbeda dengan konsep HAM yang membebaskan semua orang untuk kawin dengan siapa saja, baik ras, agama, suku, dan lainlain. Sedangkan dalam hal hukuman mati, bagi para mufasir, hak asasi itu jangan hanya dilihat dari sisi si pembunuh tapi juga dari hak asasi si terbunuh yang hilang. Hukuman mati ini juga bisa menghindarkan kerusakan lanjutan.

\section{Daftar Pustaka}

Arat, Zehra F. Kabasakal. "Forging a Global Culture of Human Rights: Origins and Prospects of the International Bill of Rights." Human Rights Quarterly, Vol. 28, No. 2 (2006).

Baidan, Nashrudddin. Metodologi Penafsiran Al-Qur'an. Yogyakarta: Pustaka Pelajar, 2000.

Dalacoura, Katerina. Islam, Liberalism and Human Rights: Implications for International Relations. London: I.B. Tauris \& Co Ltd, 1998.

Daniel Price, "Islam and Human Rights: A Case of Deceptive First Appearances." Journal for the Scientific Study of Religion, Vol. 41, No. 2 (2002).

Dembour, Marie-Bénédicte. "What Are Human Rights? Four Schools of Thought." Human Rights Quarterly Vol. 32, No. 1 (2010).

Effendi, A. Masyhur. Dimensi/Dinamika Hak Asasi Manusia Dalam Hukum Nasional dan Internasional. Jakarta: Ghalia Indonesia, 1994.

Epstein, Paul R. "Human Rights and Natural Laws." Health and Human Rights, Vol. 2, No. 2 (1997). 
Hageel (al), Sulieman Abdul Rahman. Human Rights In Islam and Refutation of The Misconceiced Allegations Associated With These Rights. Arab Saudi: King Fahad National Library Index, 1999.

Hamka, Tafsir al-Azhar. Jakarta: Pustaka Panjimas, 2003.

Ikhwan, Hak. Asasi Manusia dalam Islam. Jakarta: Logos Wacana Ilmu, 2004.

Jaṣsāạs (al), Abụ Bakr Aḥmad Al-Rāzì. Aḥkāam al-Qur'ān. Beirut: Dār alFikr, 1993.

Jauhar, Najid. "Islam, Demokrasi, dan HAM Sebuah Benturan Filosofis dan Teologis." Jurnal Ilmu sosial dan Ilmu Politik, Volume 11, Nomor 1, (2007).

Mayer, Ann Elizabeth. Islam Human Rights: Tradition and Politics. Colorado: Westview Press, 1999.

Moosa, Ebrahim. Islam Progresif: Refleksi Dilematis tentang HAM, Modernitas dan Hak-Hak Perempuan di dalam Hukum Islam. terj. Yasrul Huda. Jakarta: ICIP, 2004.

Muhamad, Simela Victor. "Pemajuan dan Perlindungan Hak Asasi Manusia Dalam konteks Hubungan Internasional dan Indonesia." Kajian, Vol. 13 No. 4 (2008).

Mulia, Musdah. Islam dan Hak Asasi Manusia: Konsep dan Implementasi. Yogyakarta: Naufan Pustaka, 2010.

Patnaik, J. K. "Human Rights: The Conœpt and Perspectives: A Third World View." The Indian Journal of Political Science Vol. LXV, No. 4, (2004): 499-514.

Rāzi (al), Muḥammad Fakhruddin b. Dịā' al-Dīn 'Umar, Tafsìr alFakhr Al-Rā̃i al-Mushtahar bi al-Tafsìr al-Kabir wa Mafatị̧ alGhayb. Beirut: Dār al-Fikr, 2005.

Rehan, Sadia. "Origin and Development of Human Rights in Islam and the West: A Comparative Study." International Journal of Social Science and Humanity, Vol. 3, No. 1, (2013).

Roberts, Glenn L. Islamic Human Rights and International Law. Florida: University of Houston Law Center, 2003.

Shelley, Louise I. "Human Rights as an International Issue." Annals of the American Academy of Political and Social Science, Vol. 506, (1989). Ash-Shiddieqy, Teungku Muhammad Hasbi. Al-Bayan: Tafsir Penjelas Al-Quranul Karim. Semarang: Pustaka Rizki Putra, 2002. - Tafsir Al-Quranul Majid An-Nur. Semarang: Pustaka Rizki Putra, 1995. 
Shihab, M. Quraish. Tafsir Al-Mishbab: Pesan, Kesan, dan Keserasian alQur'an. Jakarta: Lentera Hati, 2009. - Wawasan Al-Qur'an: Tafsir Maudhu'i atas Pelbagai Persoalan Umat. Jakarta: Mizan, 2005.

Waltz, Susan. "Reclaiming and Rebuilding the History of the Universal Declaration of Human Rights." Third World Quarterly, Vol. 23, No. 3 (2002): 437-448.

Zuhayli (al), Wahbah. Al-Tafsì al-Munir fì al-'Aqidah wa al-Sharīah wa al-Manhaj. Damaskus: Dār al-Fikr, 1998. 